\title{
MECHANISM OF TRADITION \\ IN CONTEMPORARY RELIGIOUS PRACTICES
}

\section{GÁBOR BARNA}

In the second half of the $20^{\text {th }}$ century, a new generation of believers reached back to an older religious practice, thus embracing a tradition of earlier generations and adapting it to new social and church circumstances. Tradition has been given a new function and a new social role.

In Gyöngyös, a small town in Northern Hungary, the Franciscan fathers who care for the place of pilgrimage were able to revive the pilgrimage feast of Our Mother of Sorrows by announcing a gathering of portable procession statues and images of the Carpathian Basin for the feast. In this way, the feast of Our Mother of Sorrows became a cheerful festival of young people. My paper takes this example to examine why this innovation was successful. The most spectacular characteristic of the process is the festivalisation, the creation of a lively, mass public celebration rich in events, that is, in external appearances.

Keywords: tradition, innovation, festivalisation, pilgrimage feast, gathering of portable statues, Gyöngyös (Hungary).
$V$ drugi polovici 20. stoletja je nova generacija vernikov posegla po starejsi praksi, pri čemer je zaobjela izročilo starejših rodov in ga prilagodila novim družbenim in cerkvenim razmeram. Tradicija je dobila novo funkcijo in novo družbeno vlogo.

$V$ mestecu Gyöngyös na severu Madžarske so frančiškanski brati, ki skrbijo za romarski kraj, oživili romarski praznik Žalostne Matere Božje. Za praznovanje so napovedali procesijo s prenosnimi figurami in podobami z območja karpatskega bazena. V ćlanku je predstavljen ta zgled, da bi preučili, zakaj je bila ta inovacija uspešna. Najveličastnejša značilnost je festivalizacija, stvaritev živahnega množičnega javnega praznovanja, bogatega $z$ dogodki, tj. zunanjimi oblikami.

Ključne besede: tradicija, inovacija, festivalizacija, romarski praznik, prenosne figure, Gyöngyös (Madžarska).

A quite large wooden statue of the Pietà stands in a chapel of the Franciscan church in Gyöngyös; it is regarded as a miracle-working statue and is visited by many thousands of pilgrims each year. The main pilgrim feast is 15 th September, the day of the Mother of Sorrows, in practice held on the fourth Sunday in September. The feast had begun to decline in popularity after the turn of the millennium, and the Franciscans wanted to increase its appeal by reviving a single element, the feast procession that was slowly falling into oblivion. To this end, the Franciscans announced a national meeting of portable statues. Before making the announcement they consulted a cultural anthropologist.

Ever since the Baroque age with its societies, confraternities and guilds as well as their symbols, banners, and costumes, the carriers of statues and images have been part of the pomp of the procession. However, especially in the past decades, their use has declined in many places, mainly because of the anti-religious atmosphere of socialism, but also as a result of liturgical changes. The ageing of village society and the migration of young people to continue their studies have also contributed to this effect. Unmarried girls and young men would typically carry the statues in the procession, generally wearing the typical costumes of brides and grooms of a given settlement, to which they added a blue ribbon: the colour of the Virgin Mary. 
Even the Franciscan fathers themselves did not think that the feast announced in this new form would prove to be so attractive. With the announcement of the meeting, they were reviving and relaunching a custom and movement that had almost been lost: in the first year (2006) there were only 11 portable statues present, in the second year 36 and in the third year (2009) there were 62. Clearly, the organisers had tapped into a demand of popular religiosity.

But exactly what was this demand for? Why did the national meeting of portable statues become so popular in such a short space of time? How is the event organised, how is a traditional feast changing, how is the feast itself held and, above all, what lies behind the spectacle? What mechanisms of adaptation did the organisers need to apply in using an inherited cultural pattern and how did all this influence the community concerned and the motivations for participation?

\section{SPACE, TIME AND SOCIAL MAP OF THE FEAST}

The announcement of a national meeting of portable statues proved to be an enormously powerful innovation that itself demanded a re-examination of the strategies and mechanisms for the application of that tradition and its renewal to suit the new situation.

\section{SPACE}

While in the past, processions came only from within a radius of 50 kilometres, nowadays they arrive from as far away as a hundred kilometres, and even from abroad. The attractive force of the place of pilgrimage extends to almost the whole of Eastern Hungary. Traditionally speaking, the pilgrim feast was held in the Franciscan church, the place where the miracle-workings statue of the Mother of Sorrows was kept, and this tradition was continued for the first two years of its revival. However, as the number of participants grew, there was no longer space in the church for all the pilgrims and portable statues. An open-air altar was erected in the church garden to accomodate them. The procession was held only around the church in the first two years, but now it makes its way around a whole block. The street has become the scene of the procession and the feast fair.

The pilgrim feast has thus expanded beyond the area of the church and monastery, being taken out "into the world", into the public space of the streets; in addition, the website of the Franciscans takes it into the virtual world of the Internet.

\section{TIME}

While in the past the timing of the feast - the vigil of the feast, the night of the feast, the daytime mass of the feast - was centered around the sacred statue, the highlight of the events has now shifted to the festive mass and the colourful procession following it. This Eucharistic procession has become the highlight of the feast, with groups arriving in Gyöngyös to participate with their portable statues and banners. 


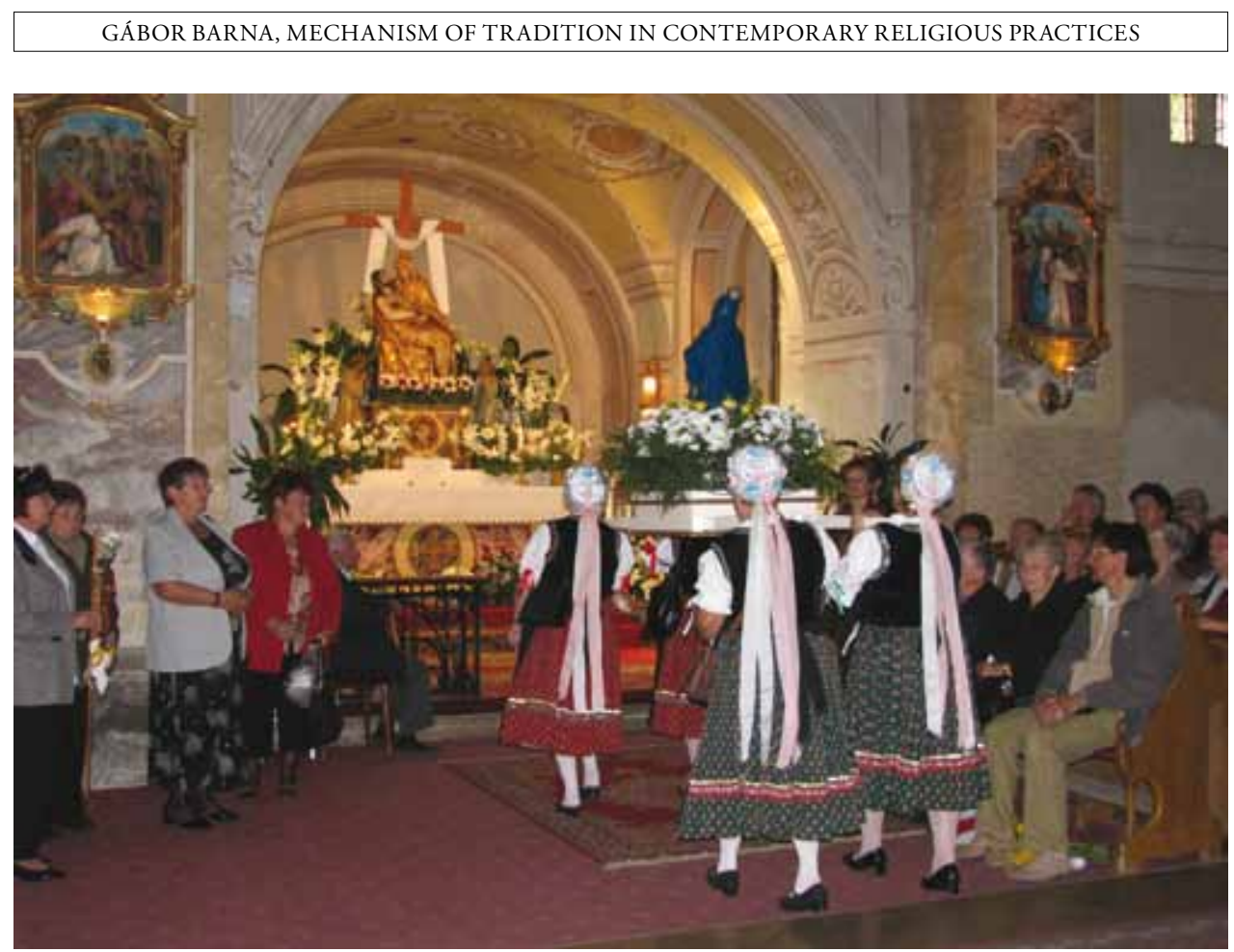

Figure 1. Greeting the miraculous statute by a Marian group (photo: G. Barna, 2009).

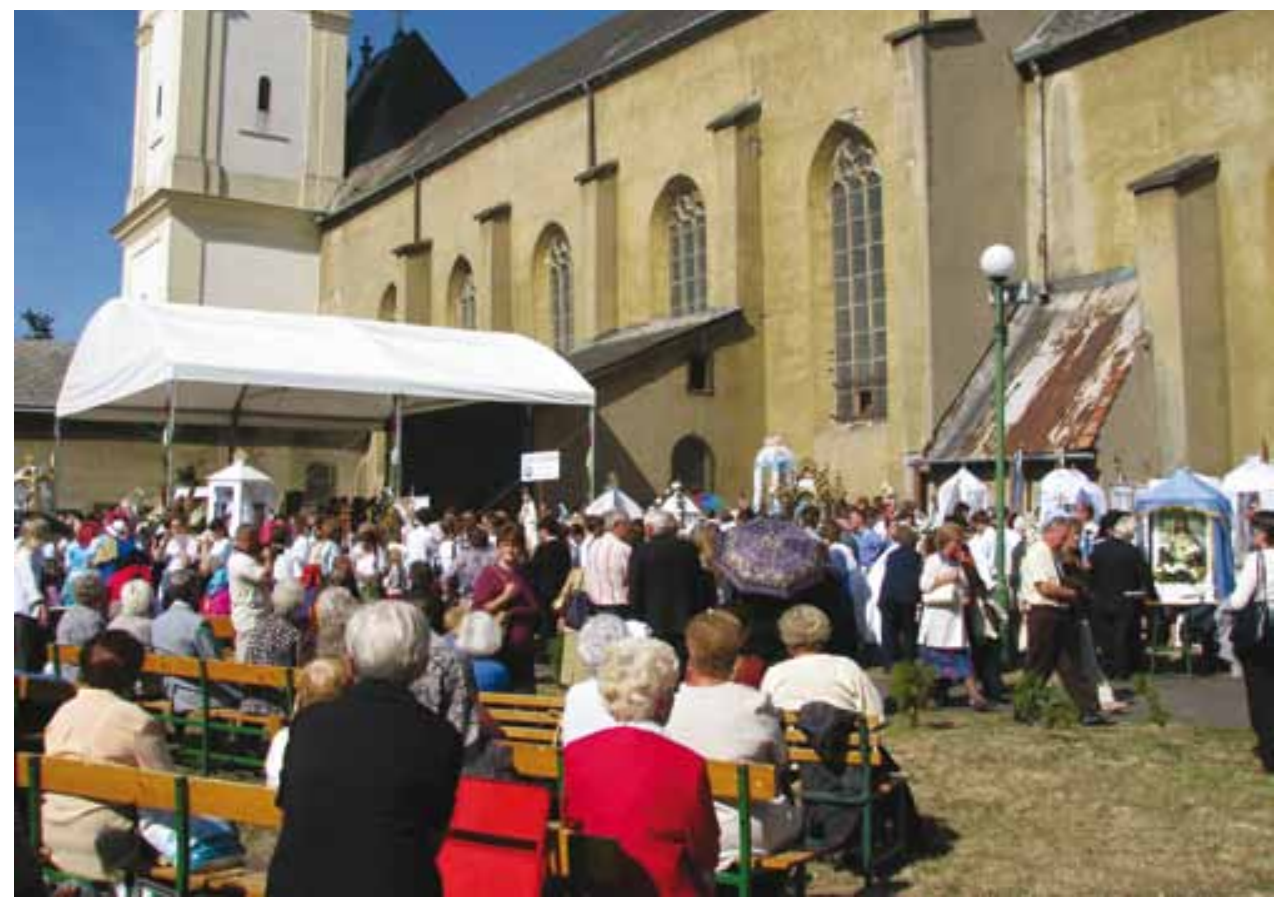

Figure 2. Open air altar in the gothic Franciscan church (photo: G. Barna, 2009). 


\section{SOCIAL ACTORS}

The festival actors were composed of the Franciscan parish and its believers, festival hosts and organisers, pilgrims arriving for the feast with special emphasis on the youngsters of Mary, and vendors selling their goods in the street. The festival participants numbered between 6000 and 7000 in 2009 . The event is starting to become an attraction, a spectacle, with large crowds of onlookers fill the streets during the procession.

The hosts. From the social perspective, such events activate local communities; they build a common sense of belonging and help celebrate and restore local customs and traditions (Karpińska-Krakowiak 2009). People participate in festivities in order to socialize and grasp creative and "authentic" experiences that differ strongly from their everyday routine. Festivals provide sensory experiences, authenticity, and uniqueness and operate as a point of identification (Karpińska-Krakowiak 2009).

The pilgrims. Those who traditionally come to the pilgrim feast and those who come for the meeting of portable statues may have differing motivations for their participation. On the one hand, local people and older people are inspired by veneration of the Mother of Sorrows and the Marian pilgrim feast. On the other hand, those coming for the meeting of portable statues are motivated by the big procession, by the opportunity to show the Marian statue and local Marian costume, and by the outward show. Differences between the age groups can also be clearly observed.

The spotlight of the event is on the Marian youth. The religious motivation for their participation is the veneration of Mary but this has been separated from the concrete festive veneration of the Mother of Sorrows. Another important source of inspiration is the cultivation of local tradition. In a number of settlements, song and dance ensembles preserving the local folk costume undertake to revive the custom of carrying the statue in response to the invitation to the pilgrim feast. The meeting in Gyöngyös has had the effect of renewing the group of statue-carrying youth in many places.

The spectators. The pilgrim feast and the meeting of portable statues is gradually becoming a tourist attraction. This aspect of the event is strengthened by the local television and Catholic radio stations, as well as by other representatives of the media.

To summarise, the invitation extended by the Franciscan monastery for a national meeting of portable statues has given impetus to the revival of local traditional customs, the renewal and display of folk costumes, and to reshaping of the identity of local communities. As a result, religious and profane motivations mingle.

As a result of the reorganisation of the Gyöngyös pilgrim feast, the portable statues and images that were originally a secondary element and intended to add to the pomp of the procession have made the national meeting of portable status and images the central element of the event. The "sorrowful" character of the feast has been pushed into the background. The older age group, people over the age of 60 , still observe the external manifestations of mourning, wearing black and merging their own sorrow, cares and mourning with the seven sorrows of the Virgin Mary. However, the presence of hundreds of young people and the 


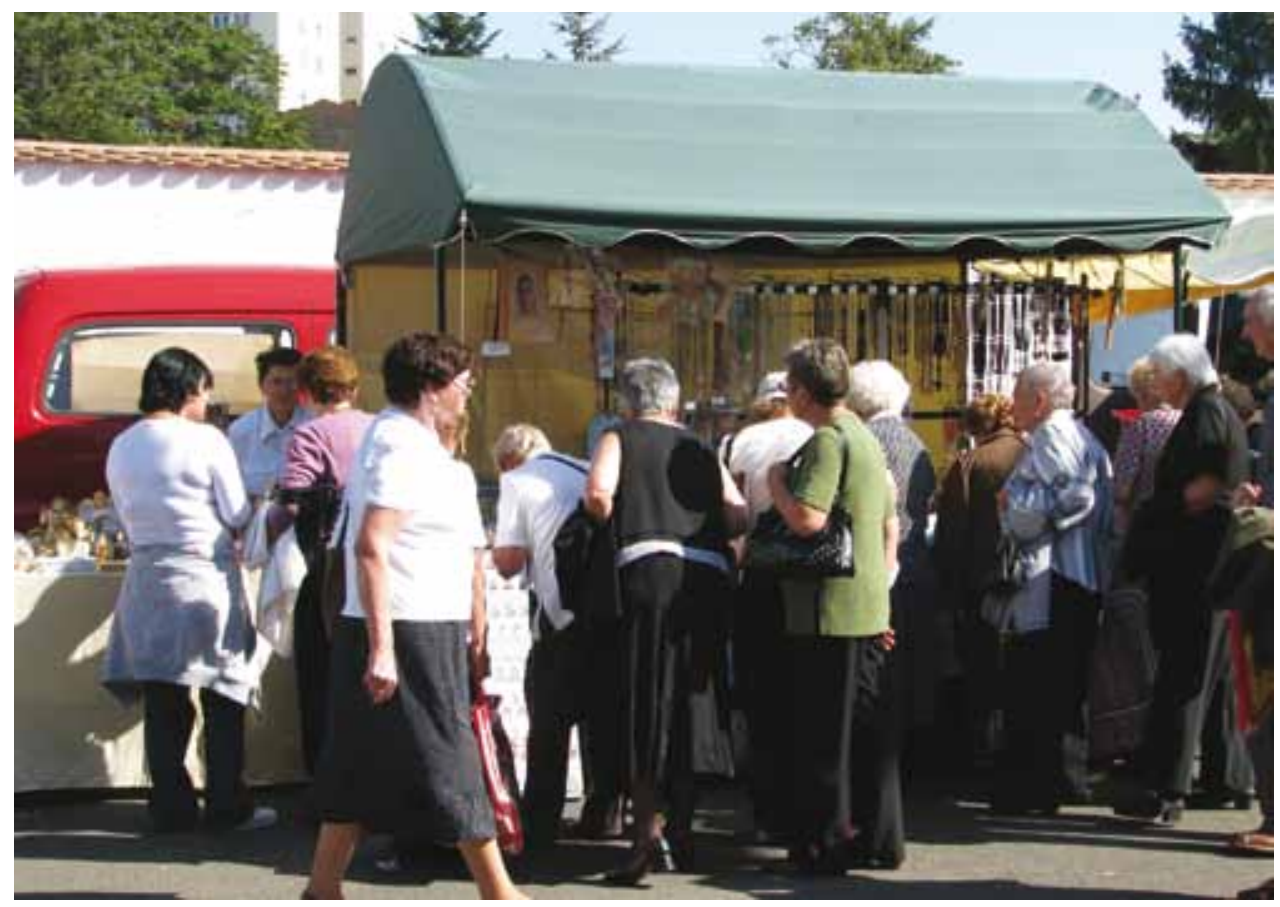

Figure 3. Buying rosaries in the pilgrim-fair (photo: G. Barna, 2009).

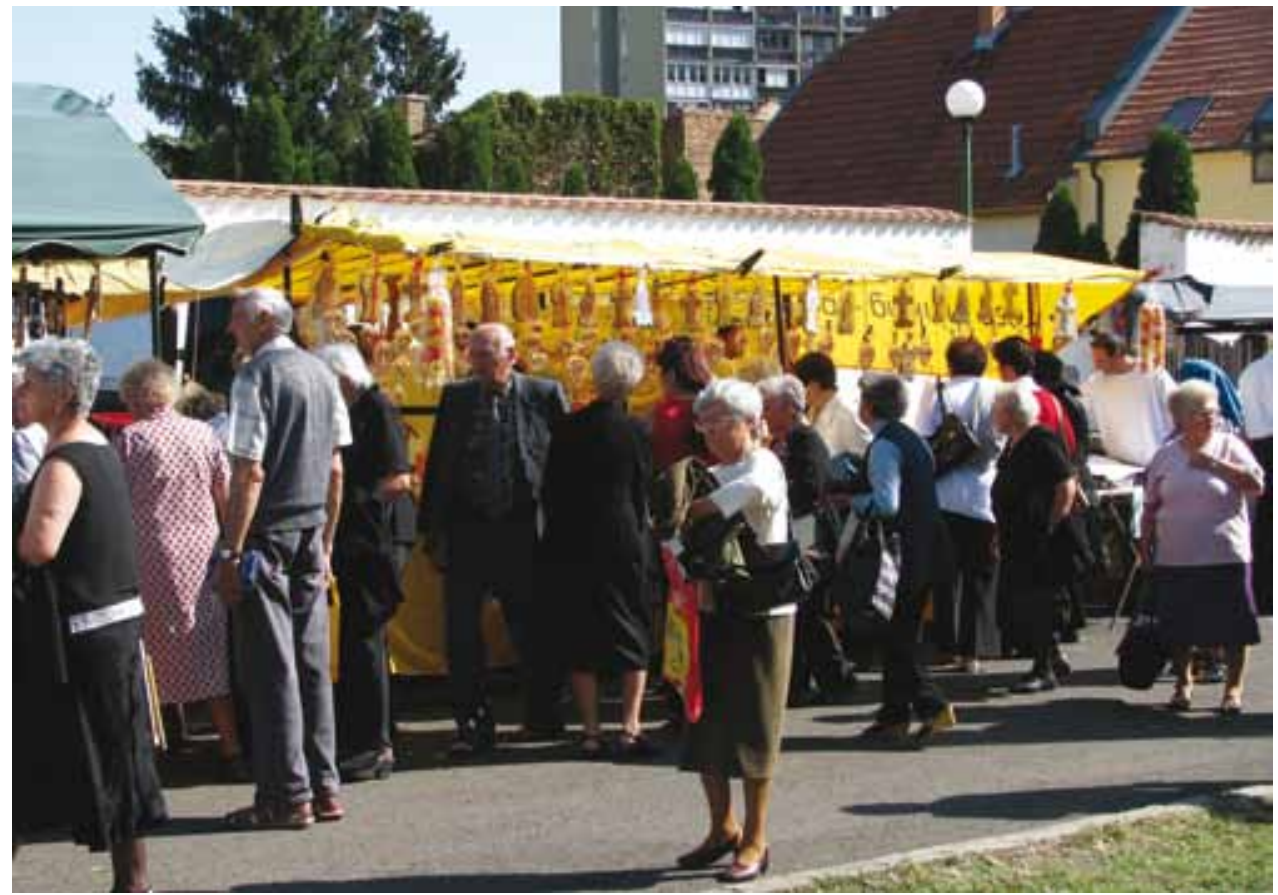

Figure 4. At the tent of the gingerbread maker (photo: G. Barna, 2009). 


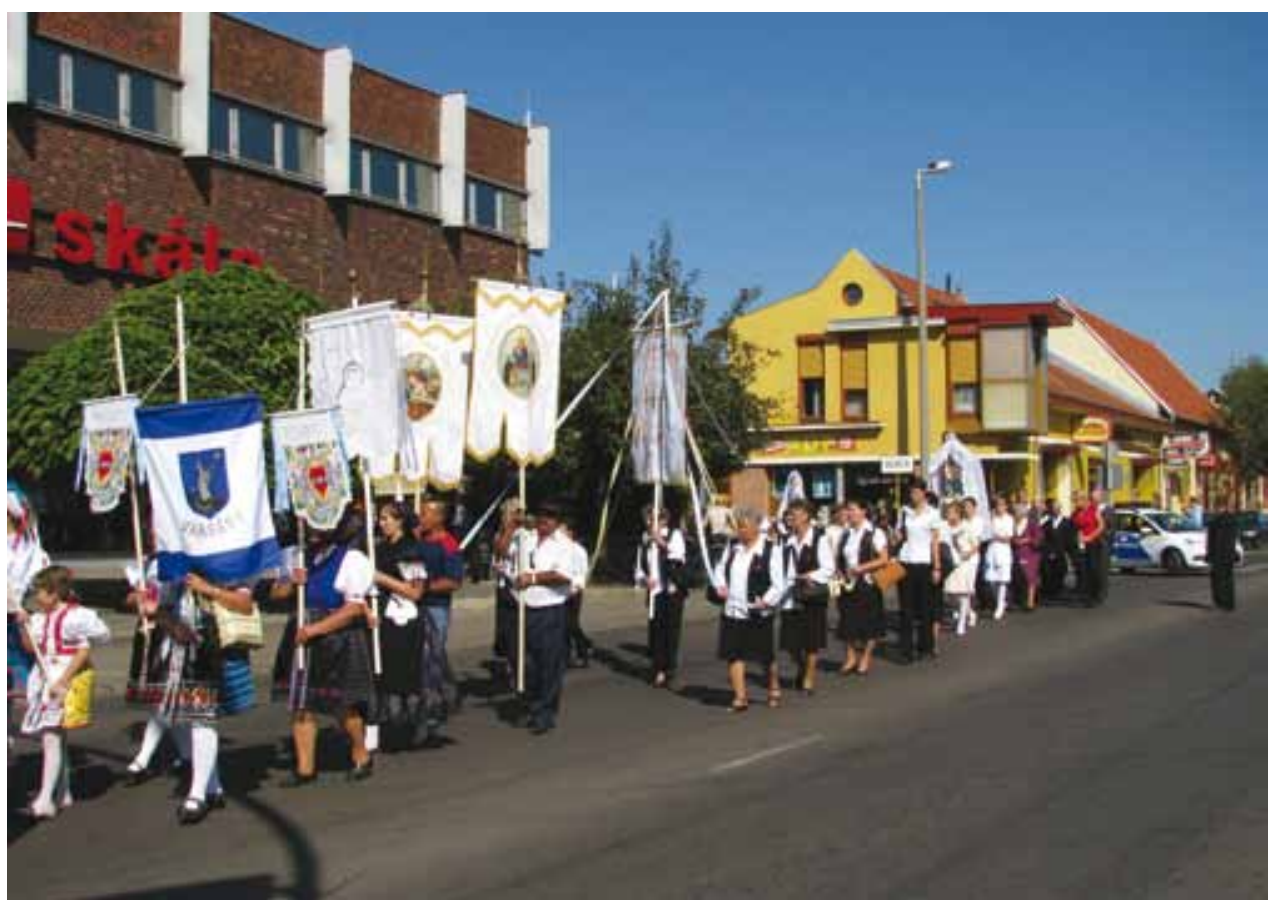

Figure 5. Pomp of the procession: portable flags, statues and folk costumes (photo: G. Barna, 2009).

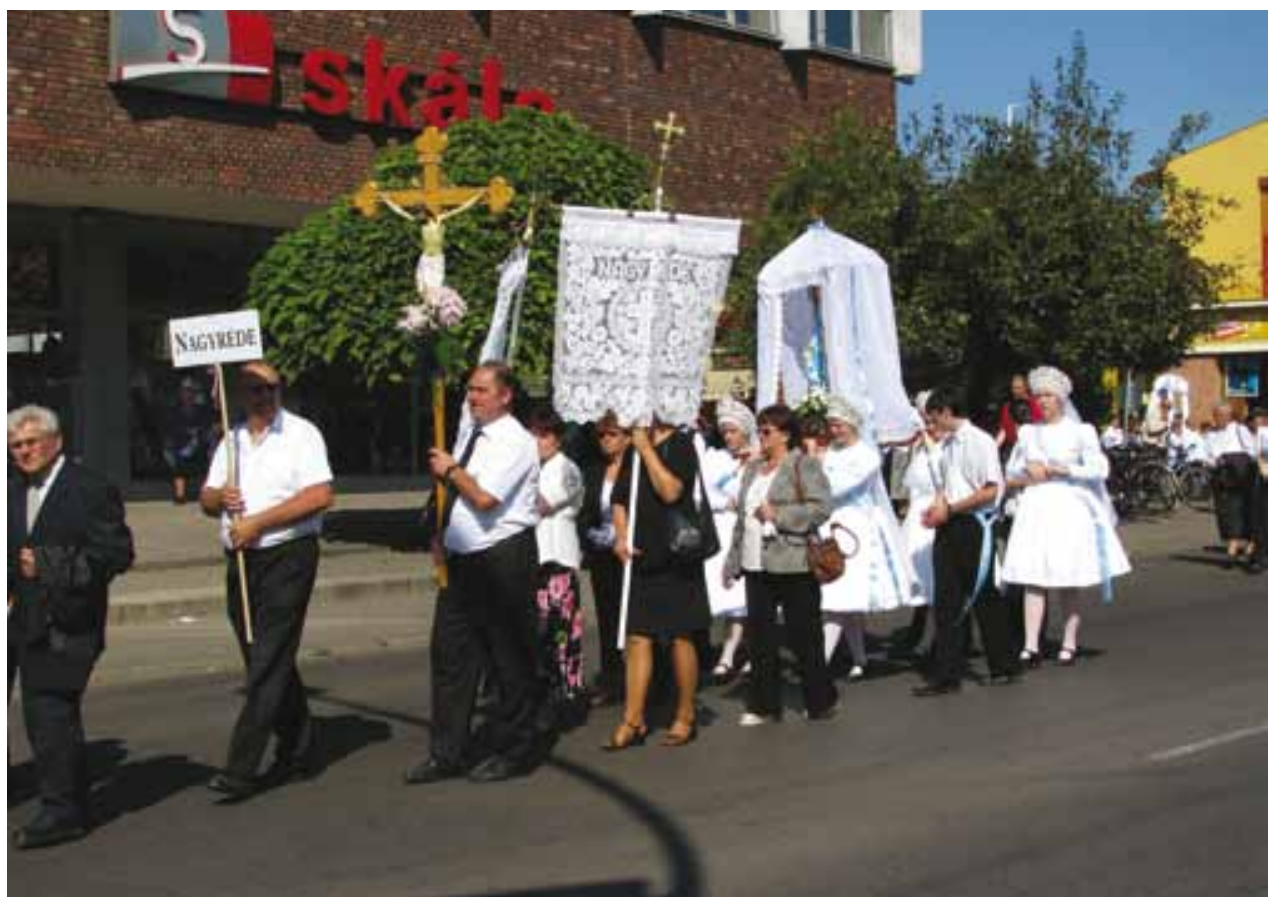

Figure 6. The Marian girls of the village Nagyréde in local costume carrying the portable statue in the procession (photo: G. Barna, 2009). 
statues of Mary they carry decorated with masses of flowers has changed the atmosphere of the feast, which now seems to have become an expression of the seven joys of Mary, a youthful, cheerful popular festival.

Sándor Bálint, the renowned professor of the Szeged department of ethnography, wrote the following of the Gyöngyös pilgrim feast in his guidebook for spiritual pilgrmas entitled As Guests of Our Blessed Lady in 1944: "The young generation of Franciscans in Gyöngyös [...] sensed that it would be impossible for our nation to find rebirth in the popular spirit without absorbing the religious culture of the people" (Bálint 1944: 65).

We can say something very similar: today's young monks in the Franciscan monastery sensed what elements of the traditional pilgrim feast they could use to address people today, especially young people. They found these elements in the external trappings of the procession in today's event- and spectacle-oriented world. However, the procession-as-spectacle has or can become an event for the confession of faith, and this may occur through the process of internalization of faith becomes internal. Yet it is also important to point out that the festivalisation of public church feasts, the mix of modernity and traditional, also brings a degree of laicisation of religious phenomena.

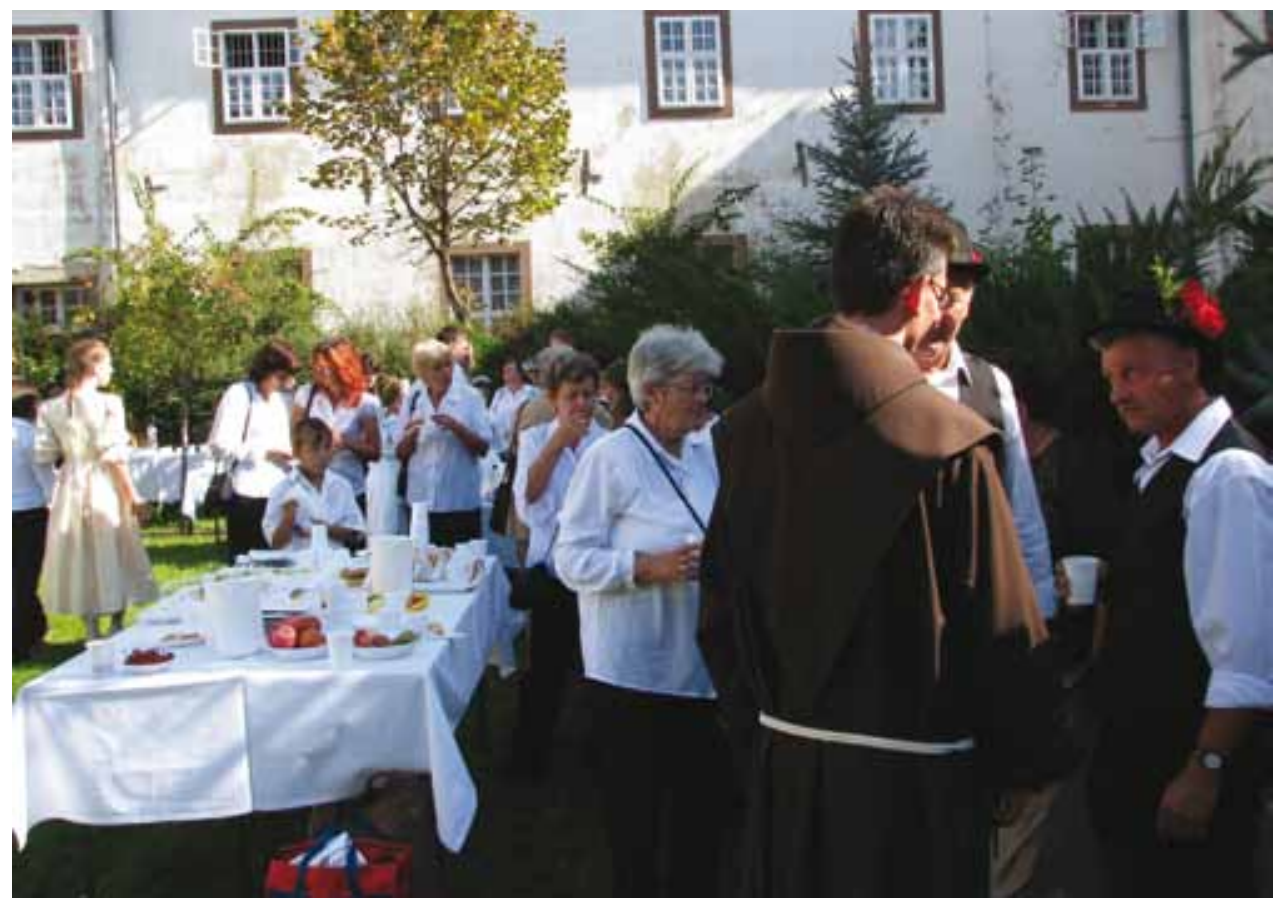

Figure 7. Agape in the yard of the cloister after the procession (photo: G. Barna, 2009). 


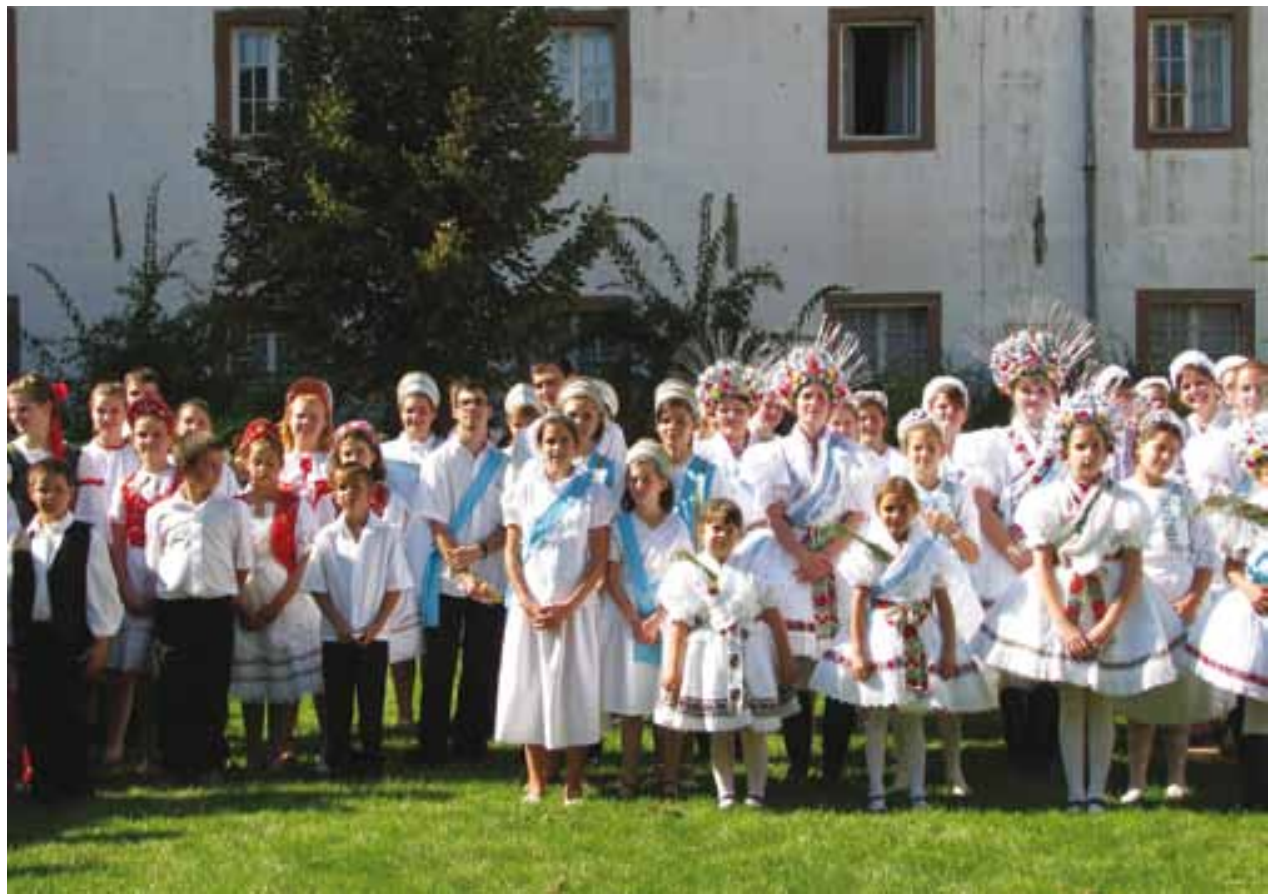

Figure 8. The Marian youth (photo: G. Barna, 2009).

\section{FESTIVALISATION OF PILGRIMAGE FEAST}

What does festivalisation mean? Mainly, the appearance of public celebrations extending beyond the boundaries of small communities, the mobilisation of large masses, and the accordance of importance to external appearances, spectacle and pomp are all key elements. The basis of festivalized pilgrim feasts is generally an "invented tradition", recreated tradition backed by settlements, various institutions, associations, or ethnic and (in our case) religious groups. In this manner a celebration is created based on a historical event or on religious/folk/ peasant/industrial/nutritional or other cultural elements and is taken out into the openness of communal space. Tourism and the media help to accord greater publicity to these events that can then take on a role in tourism and in the shaping and strengthening local and community identities.

In Hungary and throughout Europe, many state and local celebrations show evidence of the characteristic features of festivalisation. Klaus Roth speaks of the festivalisation of culture in both the eastern and western parts of Europe, although they differ in certain details (Roth 2008: 22-23). There can be no doubt that the majority of both national and religious celebrations has become festivalised (Barna 2011).

Festivals have been defined by Alessandro Falassi in the classical cultural-anthropological perspective as "a sacred or profane time of celebration, marked by special observances" 
(Falassi 1987: 2). Festivals celebrate community values, ideologies, identity and continuity. Perhaps more reflective of the modern approach to naming events as festivals, Donald Getz defined them as "themed, public celebrations" (Getz 2005: 21). The German Josef Pieper believed only religious rituals and celebrations could be called festivals. ${ }^{1}$

Festivals, religious or profane, integrate people and establish inner-communities; they induce commonly shared experiences and encourage an atmosphere of fun, pleasure and excitement. In this way, festivals facilitate the processes of transferring pleasant experiences onto other subjects, places or phenomena related to them. Festivals act as an urban image device (Karpińska-Krakowiak 2009), but they also appear in rural environments, especially in festivals of a religious nature (pilgrimages) and more recently in the growing number of profane festivals based on local gastronomic specialties (fish soup festivals, sausage festival, etc.) (Hesz 2008).

Festival studies are emerging as a distinct sub-field within event studies. ${ }^{2}$ Recently, I am now quoting Donald Getz at greater length, scholars within and outside the traditional disciplines have been examining festivals with regard to an increasing variety of issues, including their roles in establishing place and group identity (Cohen 1985: 50); the social and cultural impacts of festivals and festival tourism; the creation of social and cultural capital through festival production; the fostering of the arts and the preservation of tradition; and the variety of personal outcomes from participation in festivals, including education, the acquisition of social and cultural capital, and wellbeing. The value and worth of festivals to society and culture has been addressed, as well as the imputed need for festivity (Getz 2010: 4-5). The festival is also spectacle. It is a place, time and occasion for the representation of local cultures. Each festival, whether religious or non-religious, is a well structured cultural performance with the associated marketing and consumption features.

Tradition has always had an important and at times decisive role in religious life. However, in the last two or three centuries, tradition has been losing ground in all areas of life, including in religious life. This has been caused not only by secularisation and laicisation, but also by the increasingly sharp, at times mutually exclusive separation of the religious and the profane spheres. In the second half of the $20^{\text {th }}$ century, tradition lost much of its determining force in religious culture. This has had a number of external determinants.

In this atmosphere, a new generation of believers has reached back to an older practice and in so doing has embraced the tradition of earlier generations and adapted it to new social and church circumstances. The tradition has been given a new function and a new social role. Not only have places of pilgrimage been filled with new life, new places have also arisen. The revival of religious feasts as invented traditions has increasingly become

1 Numerous forms and themes of festival are possible, and the term festival is often misapplied and commercialised. The problem is that no widely acceptable typology has emerged (Pieper 1999: 33).

2 From economics research this became applied research in the social sciences, particularly through the work of a few researchers, such as Donald Getz. 
the singular and symbolic expressions of local and religious identity of small communities and micro-regions. We are witnessing a process of selection in which the demands of modernity become the basis for the selection of elements of tradition and their use to craft new phenomena. The most spectacular characteristic of the process is festivalisation, the creation of a lively, mass public celebration rich in events, that is, in external appearances. Lay and religious culture are moving closer together within this frame. In this fashion, religious celebrations and processions have been renewed and have also become symbolic manifestations of local culture and identity.

The core phenomenon of event studies is the event experience and meanings attached to it. Festivals are celebrations, so by definition they have a theme. They also have a variety of meanings from different perspectives that render them complex planned phenomena. Meanings exist at personal, social, cultural and economic levels. The experience itself of a festival is at once personal and social, with each form of festival (e.g. music, arts, heritage, religious) embodying different potential experiences. Event designers are particularly interested in knowing how their manipulation of setting, program and various human interactions affects the audience and/or participants, and whether or not they have achieved the desired experiences and consequences. This requires knowledge of culture, the arts, and environmental psychology (Getz 2010).

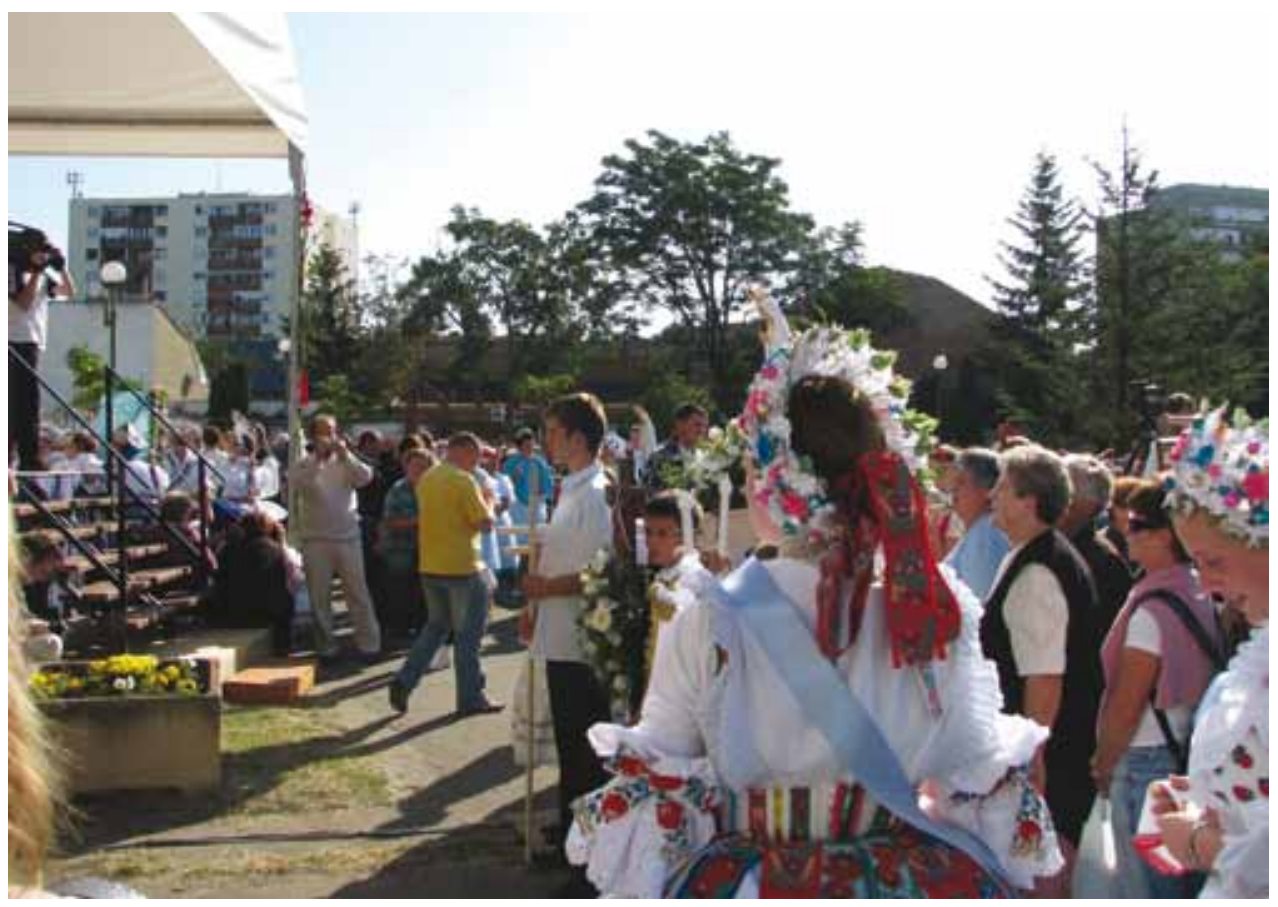

Figure 9. Pilgrims and spectators (photo: G. Barna, 2009). 
Festivals are connected to cultures and to places and help bind people to their communities. Thus, festivals and other planned events can foster and reinforce group identity as well as positive self-identification for local communities.

Festivals are, according to Josef Pieper, traditional in a very special sense (Pieper 1999: 35). In the case of festivals, tradition and innovation appear together in a specific way. The feast not only preserves but also creates tradition. This also happened in the case of the Gyöngyös pilgrimage feast, when during the course of festivalisation the organisers took one traditional element and placed it in the focus of attention. This is not only a case of mere preservation and conservation of an element of tradition, but also of a creative reshaping of the feast that accorded contemporary content to the festival (Pieper 1999: 35). In this manner, festival organizers not only changed the structure but also the character of a series of events.

\section{REFERENCES}

Bálint, Sándor

1944 Boldogasszony vendgéségében (As Guests of Our Blessed Lady). Kassa: Veritas.

Barna, Gábor

2011 Culture of Feasts Today: Commemorative Rites of National and Calendar Feasts. In: Barna, Gábor (ed.), Vallások, határok, kölcsönhatások/Religions, Borders, Interferences. Szeged: Department of Ethnology and Cultural Anthropology; Budapest: Akadémiai Kiadó, 107-114.

Cohen, Anthony P.

1985 The Symbolic Construction of Community. Routledge: London.

Falassi, Alessandro

1987 Time Out of Time: Essays on the Festival. Albuquerque: University of New Mexico Press.

Getz, Donald

2010 The Nature and Scope of Festival Studies. International Journal of Event Management Research 5 (1) (http://www.ijemr.org/docs/Vol5-1/Getz.pdf).

Hesz, Ágnes

2008 Festival and Local Identity in a Hungarian Village. In: Roth (ed.) 2008, 253-262.

Karpińska -Krakowiak, Małgorzata

2009 Festivalization of the city: Contemporary examples. Urban People/Lidé Města 11 (2) (http://lidemesta.cz/index.php?id=41\&autor=606).

Pieper, Josef

1999 (1965) In Tune with the World: A Theory of Festivity. South Bend, Indiana: St. Augistine's Press.

Roth, Klaus (ed.)

2008 Feste, Feiern, Rituale im östlichen Europa. Studien zur sozialistischen undpostsozialistischen Festkultur. Zürich and Berlin: LIT Verlag (Sozialantropologische Studien; 21). 


\section{MEHANIZEM TRADICIJE V SODOBNIH VERSKIH PRAKSAH}

V Gyöngyösu, mestecu na severnem Madžarskem, so frančiškanski bratje, ki skrbijo za romarski kraj, oživili romarski praznik Žalostne Matere Božje. Za praznovanje so napovedali procesijo sprenosnimi figurami in podobami z območja karpatskega bazena. S tem je praznik Žalostne Matere Božje postal vesel festival mladih. Za članek je to zgled, da bi preučili, zakaj je bila ta inovacija uspešna. Tradicija je v drugi polovici 20. stoletja zgubila precej določilne moči v verski kulturi. To je povezano z več zunanjimi dejavniki. $V$ teh razmerah je nova generacija vernikov posegla po starejši praksi, pri čemer je zaobjela izročilo starejših rodov in ga prilagodila novim družbenim in cerkvenim razmeram. Tradicija je dobila novo funkcijo in novo družbeno vlogo. Priče smo procesu odbiranja po zahtevah modernega časa. Gre za izbiro med elementi izročila in rabo, ki ustvarita nov fenomen. Najveličastnejša značilnost tega procesa je festivalizacija, stvaritev živahnega množičnega javnega praznovanja, bogatega z dogodki, tj. zunanjimi oblikami. Na tej podlagi so bila verska praznovanja prenovljena in ob tem, da so verska, so postala še simbolična manifestacija krajevne kulture in identitete.

Rezultat reorganizacije romarskega praznika v Gyöngyösu je, da so prenosne figure in podobe, ki so bile izvirno drugotni element, postale osrednji element dogodka, ki naj bi prispeval k veličastnosti procesije. "Žalobni značaj praznika je bil potisnjen v ozadje. Navzočnost stotin mladih in podob Marije, ki jih nosijo okrašene z množico cvetja, je spremenila značaj praznika. Danes je vtis, da gre mnogo bolj za izraz sedmih Marijinih radosti, za mladosten, sproščen, vesel ljudski festival. Festivalizacija označuje večinoma podobo javnih praznovanj, ki presežejo meje majhnih skupnosti, mobilizirajo množico, pri čemer so pomembni elementi vidne podobe, spektakel in veličastni sprevod. Njihova podlaga je v splošnem "iznajdena tradicija", torej poustvarjeno izročilo naselij, različnih ustanov, združenj, etničnih in verskih skupin, ki ustvarja praznovanje na podlagi zgodovinskega dogodka, ljudskih/kmečkih/industrijskih prehranskih ali drugih kulturnih elementov, izločenih v odprtost skupnostnega prostora. Pomembni so v turizmu in oblikovanju in krepitvi lokalnih in skupnostnih identitet.

Današnji mladi duhovniki iz frančiškanskega samostana so čutili, katere elemente tradicionalnega romarskega praznika labko uporabijo, da bi nagovorili ljudi danes in posebej mlade. V danšanjem dogodkovno in k spektakularnemu naravnanem svetu so jih našli v zunanjem blišcu procesije. Procesija kot spektakel je postala ali lahko postane dogodek za izpovedovanje vere.

Seveda je veliko pomembnih nacionalnih in verskih praznikov, ki so prav tako festivalizirani; to je razvoj, značilen za Evropo kot celoto. Za majhno lokalno skupnost je čaščenje krajevnega svetnika ali krajevne dedišcine ena pomembnejših stvari v letnem koledarju. Kakor v predstavljenem primeru. Na Madžarskem je festivalizacija cerkvi posvečenih praznovanj, spominskih dni zavetnikov, procesij pojav zadnjega časa.

Prof. Dr. Gábor Barna, Department of Ethnology and Cultural Anthropology, University of Szeged, Egyetem u. 2, H-6722 Szeged, Hungary, barna@hung.u-szeged.hu 